\title{
Development of household savings and debts in small open economies during the global pandemic COVID 19
}

\author{
Milena Botlíková ${ }^{1, *}$, Josef Botlík ${ }^{2}$, and Jana Stuchlikovál \\ ${ }^{1}$ Silesian university in Opava, , Faculty of Philosophy and Science, Masarykova trida 343/37, \\ 74601 Opava, Czech Republic \\ ${ }^{2}$ Silesian university in Opava, , Administration Business Faculty in Opava, Univerzitní náměstí \\ 1934/3, 74430 Karviná, Czech Republic
}

\begin{abstract}
Research background: Global pandemics, like other crises, is reflected in financial decision-making. For many individuals, the crisis represents a loss of confidence in the economy; fears of losing their jobs, and by analogy, subjects assume a deterioration in their own economic situation. In relation to income shocks, consumers exhibit three types of financial behavior: realizing consumption, generating debt or generating savings. The growth of savings with the entrepreneur's investment restraint, increasing the debt burden significantly affects the social sphere and the economic competitiveness of the region in the global space.

Purpose of the article: The article deals with a comparison of the development of savings and household debts in Czechia during the economic crisis and the development during the pandemic. At the same time, the analysis includes a comparison of the values $f$ the development of savings and debts with the development of the consumer confidence indicator in the given period.

Methods: The main method of the paper is analysis, comparison of data and prediction of the development of quantities. Quarterly and monthly data for the period 2009 - 2013 and 2020 - 2021 were used for the analysis. Basic for analysis and comparison was represented by the ARAD databases, the Czech Statistical Office, etc.

Findings \& Value added: The results show that the more dynamic growth of savings in the pandemic was caused by limited consumption, but also by wage growth. Debt growth was more pronounced during the economic crisis, during the pandemic it is a reflection of housing needs and developments in the real estate market.
\end{abstract}

Keywords: Households; Czech Republic; pandemic; savings

JEL Classification: $C 1$; $G 51 ;$; 65 ;

\footnotetext{
* Corresponding author: milena.botlikova@,fpf.slu.cz
} 


\section{Introduction}

Many households save during their life cycle; the aim is to finance the reduction of income in old age, their children's studies or real estate purchases. The Covid 19 pandemic has affected all spheres of life in the global space. There is no denying that the pandemic has affected many lives. From an economic point of view, a pandemic is likened by many experts to a black swan, similar to the credit crunch (Taleb, 2007; Newmeyer, 2021 ), i.e. a pandemic crisis occurred without anyone anticipating it. However, Taleb, 2007 refuses to evaluate the situation of Covid-19 as black swans, governments could react much faster, and the signs of disaster were clear. Other experts think that the pandemic fits into the "theory of white swans" or the "grey rhino" (Huang, 2020). In any case, the pandemic has crippled the economic life of the population, global economic flows have stopped, and we can consider pandemic as the cause of supply and demand shocks (Beck and Janus, 2016). Savings are an essential source of financing business investment and budget deficits in the economy. On the one hand, from the household's (microeconomic) point of view, the low savings rate is an economic factor in reducing the quality of life. The need for household savings is indispensable in times of economic and social fluctuations. On the other hand, savings are an accelerator of inflation. It can be stated with certainty that there is a relationship between household savings and economic development.

\section{Financial behaviour}

The level of savings or indebtedness depends on many factors. Shinem et al. believe that incomes and motivate households to influence the level of savings. According to Laoyza (2000), estimated growth coefficient indicates that an increase in the income growth rate by 1 percentage point leads to a private saving rate increase of 0.45 percentage points in the short run. There is a general awareness that wealthier people save more. According to Friedman's hypothesis of a permanent pension (HPD), the savings adjust to their expectations. From accidental over-revenues (one-off increased revenues), funds accumulate for consumption in the future, but with the classic increase, the consumer will increase consumption. On the contrary, according to Campbell and Mankiw (1989), up to 50\% of people do not behave in this way and use their one-time above-standard income for increased consumption. Canzoneri (2015) state that entities are motivated to save based on interest rates. At high deposit rates, they are motivated to save; low-interest rates do not motivate them to save. The level of the savings rate also depends, for example, on the expected unemployment rate. Concerns about losing a job lead to savings for a period of no income. Another factor in creating savings is the slowdown in economic activities, as is the case with pandemic lockdowns and the impossibility then of realizing consumption. In times of denial of consumption and fears of losing a job, classic savings are generated, i.n. ordinary saving and savings caused by caution and by forcing. In worse times, at a time of rising unemployment, people are saving more and increasing their debt more. The use of a loan instrument by households is nothing special; it testifies to the maturity of the economy. According to R. Lucas, short-term lending allows for fluctuations in consumption (Pasalicova and Stiller, 2004).However, the easy availability of credit, associated with financial liberalization, reduces private savings households (Grigoli et al., 2018; Loayza et al., 2000).

Financial decision-making influence the demographic character of the population, such as the age of the population (Grigoli et al., 2018; Pasalicova and Stiller, 2004, Cagetti, 2003), patterns of family behaviour, shopping tourism trends (Mitriková, et al. 2016) or the culture of the region (Ye, et al., 2021). Research by Zhu and Chou (2018), shows a higher level of retirement savings for people over the age of 44; they see the need to secure themselves for a time when income will fall, while the younger generation prefers higher consumption and does not see the need to save for retirement. Kim and Chatterjee (2013) admit to some extent that people who held financial responsibility, as children (financial management with parental control), are more financially literate in adulthood and are aware of the need to save. In the youth segment with a high level of financial ownership of the family, there is a low level of 
motivation to generate savings. Heterogeneity in saving depends on different motives; however, political reforms and government decisions can significantly influence these motivations (Schunk, 2009; Fisher and Montalto, 2010).

\section{Methods and data}

Shiba (2015) compared the values of household deposits (savings deposits) to net material product and GDP interregional. In their study, Laoyza et al. (2000) use a regression analysis model to predict savings rates. He used the size of income for the assessment, further divided factors into financial variables (real interest rate, the share of M2 in the gross national product (M2/GNP), etc.), financial policy factors (public finances, public consumption, etc.), demographic development factors (urbanization ratio, age structure, young dependency ratio) or macroeconomic uncertainty factors (inflation rate).). The article aims to evaluate the development of savings and household indebtedness, which are essential creators of national savings necessary for economic growth. The research was based on a comparison of two crisis periods. Specifically, it compares quarterly data for 2007-2011, i.e. the period of the financial crisis and the period $2019-2021$, which is partly marked by the Covid-19 pandemic. Although both periods were affected by the crisis, each of these crises had its specifics. The goal is to assess the development rate of saving (in paper take savings rate, SR) and debts. For savings rate values were used, based on a comparison of savings and gross disposable income (GDI), which represents the amount households can spend on final consumption, financial assets and the accumulation of tangible and intangible assets active. This indicator is commonly used in evaluating the development of savings in the literature. The level of savings compared with the size of GDI, consumption, the development of expected and actual unemployment. Year-on-year and quarter-on-quarter changes are calculated as growth rates $(\mathrm{Qi}-\mathrm{Qj}) / \mathrm{Qj} * 100$, expressed as a percentage. The estimate of the development of the savings rate in the absence of a pandemic or financial crisis was based on the share of the average value of the savings rate (11.6\%, average for the period 1999-2006) in gross disposable income. The difference between the resulting values and the actual value of the savings rate is made up of prudential and forced savings (metod Michálek and Slezáková, 2021, is based on real disposable income). For the analysis of indebtedness, indicators of housing loans and consumption were chosen, which were measured against the interest rate. Data from the ARAD information system of the Czech National Bank of the CNB ARAD database were used to analyze the structure of savings and indebtedness.

\section{Analysis of household savings}

In 2020, households in the Czech Republic produced a $21.05 \%$ gross savings rate. Compared to the V4 countries, the Czech Republic is better than Slovakia (10.85\%). If we compare the development of the savings rate over a 10 -year horizon, was Czechia the second country among the V4 countries after Hungary, with the highest gross savings rate (except for 2019 - 2020, in that year, the Czech Republic was the first). Slovak households are better off in savings than in Poland. Among the $18 \mathrm{EU}$ countries, it is in the top five (more Eurostat, 2021a). If we look at the current development of the gross savings rate calculated as the share of savings in gross disposable income, it is clear that during the financial crisis in 2008 savings were formed, however, but they did not experience such acceleration as during the pandemic. The savings rate reached $20-25 \%$ at the end of 2020 and the beginning of 2021 (see figure 1). The $12 \%$ increase in deposits compared to the average is the highest since 1997 (average 1997-2020: 12.5\%). Households have accumulated in real terms about 4.2 times more savings, ie deposits adjusted for household mortgage debt than on average every year in the previous almost twenty years. 


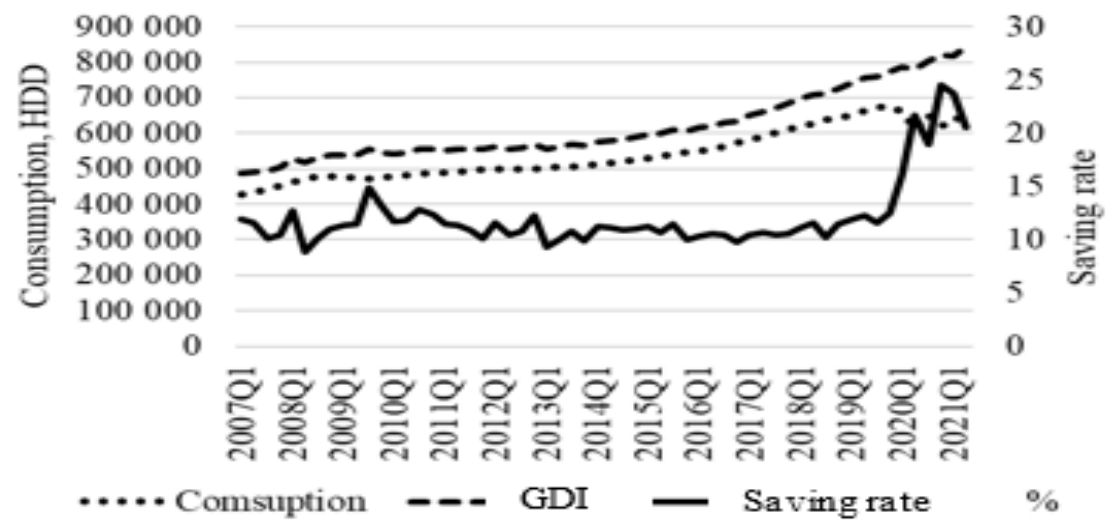

Figure 1. Development of the rate of savings \%, consumption and GDI (in million CZK).

Source: CNB, owen processing (2021)

The implementation of state measures in 2020 , led to an increase in gross disposable income, except for the period Q1/2021_Q4/2020.. On the contrary, household consumption decreased, except for 3Q-2Q/2020 and Q2-Q1/2021. In connection with the development of variables, household savings grew during the period of restrictions, mainly restrictions on the services segment (see table 1).

Table 1. GDI development, savings and household consumption rate (in\%).

\begin{tabular}{|c|c|c|c|c|c|c|c|}
\hline Period & $\Delta$ SR & $\Delta$ GDI & $\Delta \mathbf{C}$ & Period & $\Delta$ SR & $\Delta$ GDI & $\Delta \mathbf{C}$ \\
\hline Q1-20/Q4-19 & 20.9 & -5.5 & -8.8 & Q1/2020-2019 & 29.6 & 6.3 & 1.3 \\
\hline Q2-20/Q1-20 & $\mathbf{2 6 . 7}$ & 2.7 & -3.2 & Q2/2020-2019 & 79.5 & 4.4 & -7.4 \\
\hline Q3-20/Q2-20 & -16.0 & 2.5 & $\mathbf{7 . 1}$ & Q3/2020-2019 & 57.0 & 5.3 & -3.0 \\
\hline Q4-20/Q3-20 & $\mathbf{3 9 . 6}$ & 6.3 & -3.1 & Q4/2020-2019 & 78.9 & 5.8 & -8.5 \\
\hline Q1-21/Q4-20 & -2.2 & $\mathbf{- 6 . 4}$ & -5.8 & Q1/2021-2020 & 44.8 & 4.7 & -5.5 \\
\hline Q2-21/Q1-21 & -20.9 & 5.3 & $\mathbf{1 2 . 6}$ & Q2/2021-2020 & -9.3 & 7.4 & 10.0 \\
\hline
\end{tabular}

Source: CNB, owen processing (2021)

Year-on-year (2020-2019), there was up to an $80 \%$ increase in savings, and GDI in 2020 also grew throughout the period under review. Compared to 2019, consumption was lower in 2020, i.e. the value of the year-on-year change was negative. We can undoubtedly consider rising wages and reduced consumption as the cause of the year-on-year increase in savings. The inverse period in the year-on-year change is Q2/2021 when after five quarters, there was an increase in GDI and an increase in consumption while reducing the value of the savings rate by $9.3 \%$ (for more details, see Table 1). It should be emphasized that a vital determinant eliminating the decline in consumption at the time of covid 19 was the rapid adaptation of companies and households when the market could move to an internet platform. A comparison with the development of the financial crisis shows that in the period 20082011, there was also a higher increase in the savings rate (Q3/2009: by 33.28\%) and their sharp declines (Q1/2008: by $37.96 \%)$. The low level of savings during the recession was mainly influenced by creating current and prudential savings. Households were hit by high inflation of $6.3 \%$ in 2008 (2020: 2.3\%), high unemployment at 7\% and wage declines in 2011 (see Figure 2, Table 1, for more details).

Residents are increasingly holding funds on demand deposits, while the share of deposits in term deposits is declining. In the case of both crises, this fact can be explained by the effort of households to have a sufficient amount of highly liquid funds available. This theory is also supported by the increase in the volume of deposits on short-term time deposits during the financial crisis in 2009 , which declined after the fading crisis. The household's effort to have liquidity supports the behaviour at the beginning of the pandemic, when, according to Ducháček, the amount of currency held by households increased, people needed to pre-supply money, similarly to food. 
The decline in the use of term years is also associated with declines in interest rates on these products. Therefore, if they use this product, then in the form of long-term and medium-term. Where revenues from deferred consumption are higher. During the period 2011, deposits of life insurance, pension and standardized guarantee program grew, the growth trend continues to the present day. From 2019, households are starting to invest more heavily in shares and participation certificates, which, on the contrary, have declined during the financial crisis.

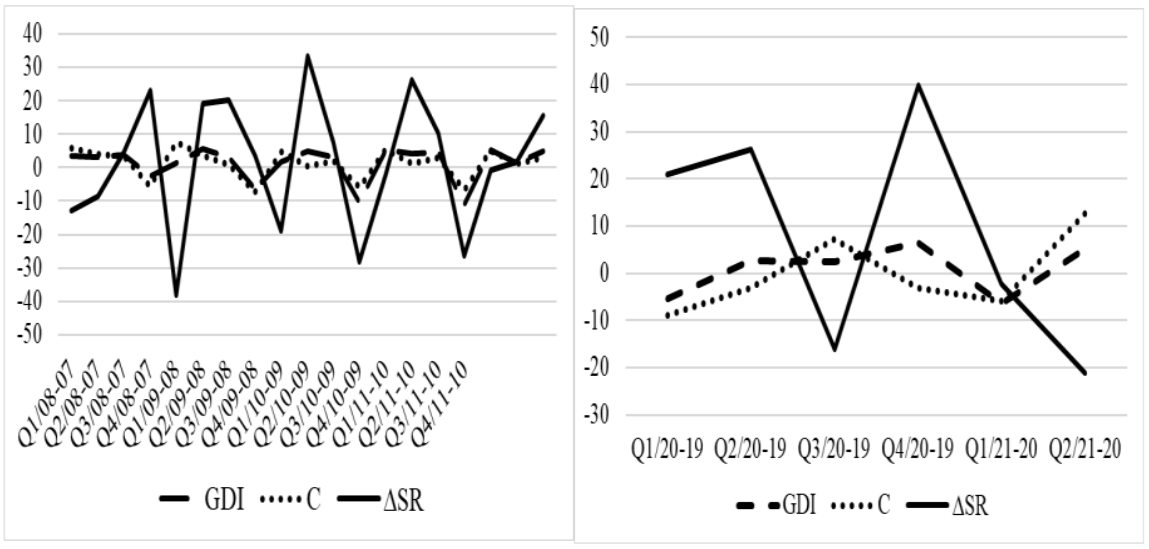

Figure 2. GDI development, savings and household consumption rate (in\%) QY-o-QY.

Source: CNB owen processing (2021)

Based on the estimated development of savings (crisis-free economy, Figure 3B), we can observe that the actual savings in 2020 exceeded the estimated savings, defacto common. The increase is mainly due to denied consumption during blockage and the suppression of unemployment through government measures. Furthermore, it can be assumed from comparing the expected and actual development of unemployment (research CVVM) with the savings rate, we can assume that also were generated cautious savings.

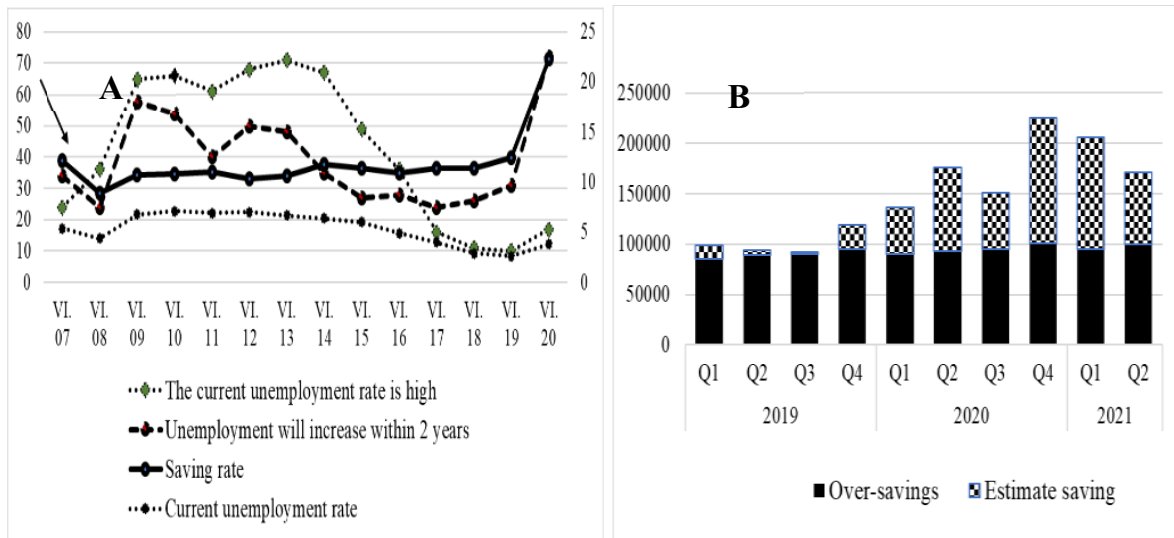

Figure 3. (A) Development of unemployment and savings rates (in \%) and (B) Estimation of forced and prudential savings (in million CZK).

Source: Tuček, owen processing (2020)

In the case of a recession, the development of the savings rate corresponds to the curve of the unemployment rate; in the pandemic period, the correlation of the savings rate with the prospect that unemployment will increase within two years. (see figure $3 \mathrm{~A}$ ). Regarding the relationship between the savings rate and interest rates (on savings accounts, with a notice period agreed to maturity, on current accounts), the savings rate copies the development of interest rates with the notice period that was the highest bid. 


\section{Household indebtedness}

The debt-to-gross disposable income ratio of households (including non-profits serving households) in the Czech Republic was around 58\% in 2019. Similarly, Poland's people are indebted. In the Czech Republic, it amounts to over 2 trillion Czech crowns in 2020. Housing loans (57\% in 2007; 75\% in 2020) and consumer loans account for the largest share of total indebtedness (Eurostat, 2021b). The dynamics of consumer loans are not as progressive as for housing loans. The total volume of indebtedness for household housing is gradually increasing (from the beginning of the crisis Q1/2020 to Q2/2021 CZK 175,500 million); there was an increase in volumes in banks and credit unions, the decline in housing loans in other banks is declining (Q1/2020 - Q1/2021 by CZK 60 million). Consumer loans increased by CZK 1,681 million in the period Q1/2020 to Q2/2021, which was taken care of by banks and credit unions, and in other banks, they recorded a decrease in volumes (Figure 4).
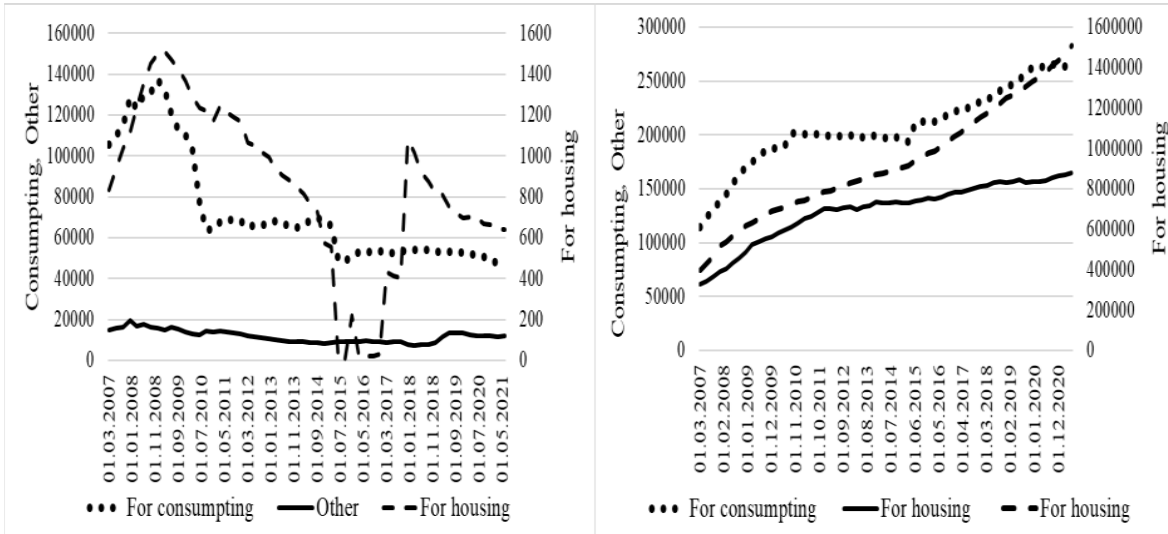

Figure 4. Development of household debt in millions of CZK.

Source: CNB owen processing (2021)

Quarter-on-quarter changes in loans during the pandemic gradually slowed down. The beginning of the pandemic dampened demand for consumer loans. Compared with Q2/2020 and Q1/2020, the growth rate in this segment of loans decreased by $0.48 \%$. Subsequently, these declines have repeated in the period Q4/2020, compared to Q3/2020 and Q1/2021-Q4/2020. This slowdown may be caused by a downturn in the economy, the complete closure of services. On the other hand, housing loans still achieved favourable growth rates, higher in the third and fourth quarters of 2020 and Q2/2021. These periods are typical for construction. Only in Q1 / 2021-Q4 / 2020 decreased demand subjects during the pandemic (see Table 2).

Table 2. Development of quarter-on-quarter credit growth rates (in \%).

\begin{tabular}{|c|c|c|c|c|}
\hline Period & Total & Consumpiting & Housing & Other \\
\hline Q1-20/Q4-19 & 5.91 & 0.11 & 1.44 & -0.58 \\
\hline Q2-20/Q1-20 & 1.22 & -0.48 & 1.87 & 0.36 \\
\hline Q3-20/Q2-20 & 1.70 & 0.54 & 2.12 & 1.54 \\
\hline Q4-20/Q3-20 & 1.54 & -0.73 & 2.31 & 1.26 \\
\hline Q1-21/Q4-20 & 1.29 & -0.64 & $\mathbf{1 . 9 8}$ & -0.01 \\
\hline Q2-21/Q1-21 & 2.41 & 1.86 & 2.80 & 1.15 \\
\hline
\end{tabular}

Source: CNB owen processing (2021)

In the last five years, the rate of various loans has fluctuated at $5 \%-8 \%$. During the pandemic, there was a year-on-year increase in loans provided (2020-2019 and 2021- 
2020); the growth rate ranged from 5.3\% to 7.1\% from Q1/2020-2019 to Q2/20212020. Its growth was mainly due to the growth rate of housing loans, which showed a growing trend throughout the period. Low interest rates probably triggered the upward trend. On the other hand, the year-on-year growth rate of loans slowed down the yearon-year growth rate of loans in consumer credit. During the covid-19 pandemic, there was a year-on-year decline in these loans in Q4/2020 compared to Q4/2019 and subsequently in Q1/2021 compared to Q1/2020. The last observed period (Q2/20212020) marked a $1 \%$ recovery in the consumer credit market. A similar trend in the growth rate as housing loans, except for Q2/2020-2019, shows the development of other loans. On the contrary, the period of the financial crisis, after high year-on-year increases in loans provided in the period Q1/2008-2007 to Q2/2009-2008 (growth rate $27.7 \%-10.3 \%$ ) showed a slowdown and in Q2-Q4/2010-2009 declines (average growth rate $-1.5 \%$ ). These declines are the result of the negative growth rate of consumer credit. (see figure 5). The annual growth rate of housing loans has been slowing throughout the financial crisis. The end of the period under review is a period of growth in total loan volumes $(0.28 \%$ to $5.53 \%)$. See Figure 5 for details.
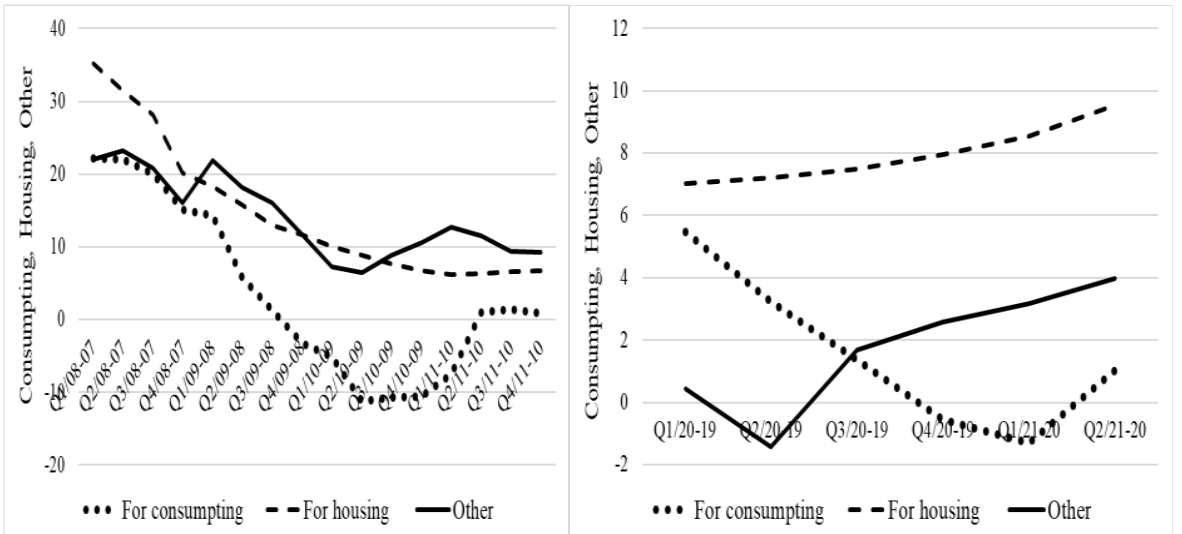

Figure 5. Development of credit during the financial and pandemic crisis QY - o - QY (in \%).

Source: CNB owen processing (2021)

The primary aspect for deciding on the commitment of households is not only their financial situation, i.e. disposable income, but also the level of interest rates on loan products.
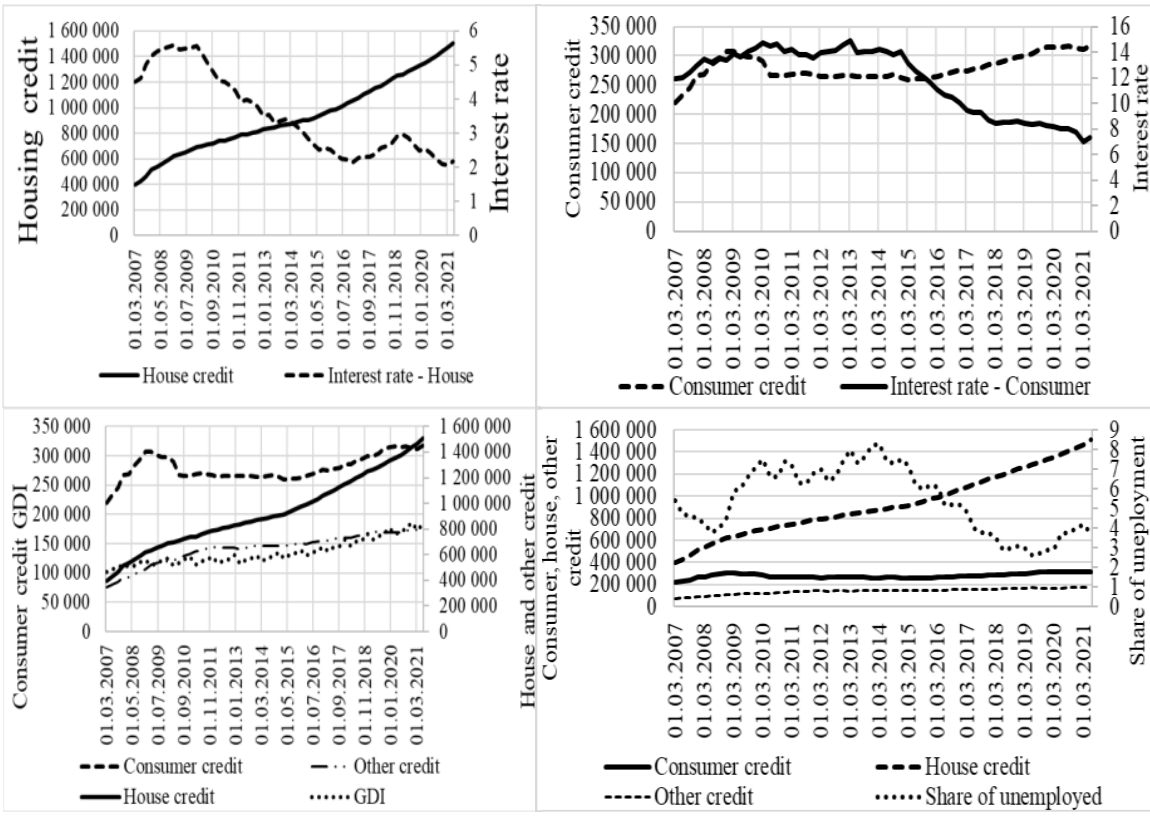
Figure 6. Development credit, GDI, (in mil.CZK), Interest rate, Share of uneployment (in $\%)$.

Source: CNB owen processing (2021)

The theoretical basis speaks take of actual or expected unemployment. Data analysis shows that the volumes of loans correlate with the amount of disposable income (the value of the correlation coefficient $r=0.9$ ). Furthermore, it can consider the relationship between interest rates and the volume of loans. In Figure 6, it is clear that the variables on the volume of housing loans and interest rates are inverse. Then, with rising interest rates, households are likely to lose their willingness to enter into significant commitments. Consumer loans have also shown a similar development since 2016. Figure 6 also shows that the volume of consumer credit increased at the beginning of the financial crisis despite rising interest rates. In the case of unemployment and the importance of loans, it is impossible to determine the relationship.

\section{Results}

The dynamic increase in savings will be replaced by a decline in the household savings rate. Although the savings rate is projected to decline, it can be assumed that the savings rate (Q2/2020-2019 decrease of 7.5\%; Q4/2022-2021 decrease of 5.01\%) to 2022 will not fall below the 2020 level. It is clear that this development of household savings has been unprecedented since the late 1990s. The level of savings is estimated for 2022 at $18 \%$ As for loans, with increasing development it is predicted only for other loans, consumer and mortgage is heading for a slowdown (see figure 7). It is clear that the development of housing loans had differently developments during the financial crisis and the pandemic. The initial increase in mortgage loans at the beginning of 2021 will be replaced by a decline in growth dynamics. A similar development in during both crises was reflected in consumer and other credit, where declines replaced the increase in the dynamics of development. However, the forecast from 2021 until 2022 shows an increase in the rate of other loans, while the growth rate of consumer credit will slow down (see figure 7). In all probability, it can be assumed that the development of demand for loans is associated with the development of interest rates and the amount of disposable income. In the case of savings, the relationship with unemployment, interest rates and consumption.

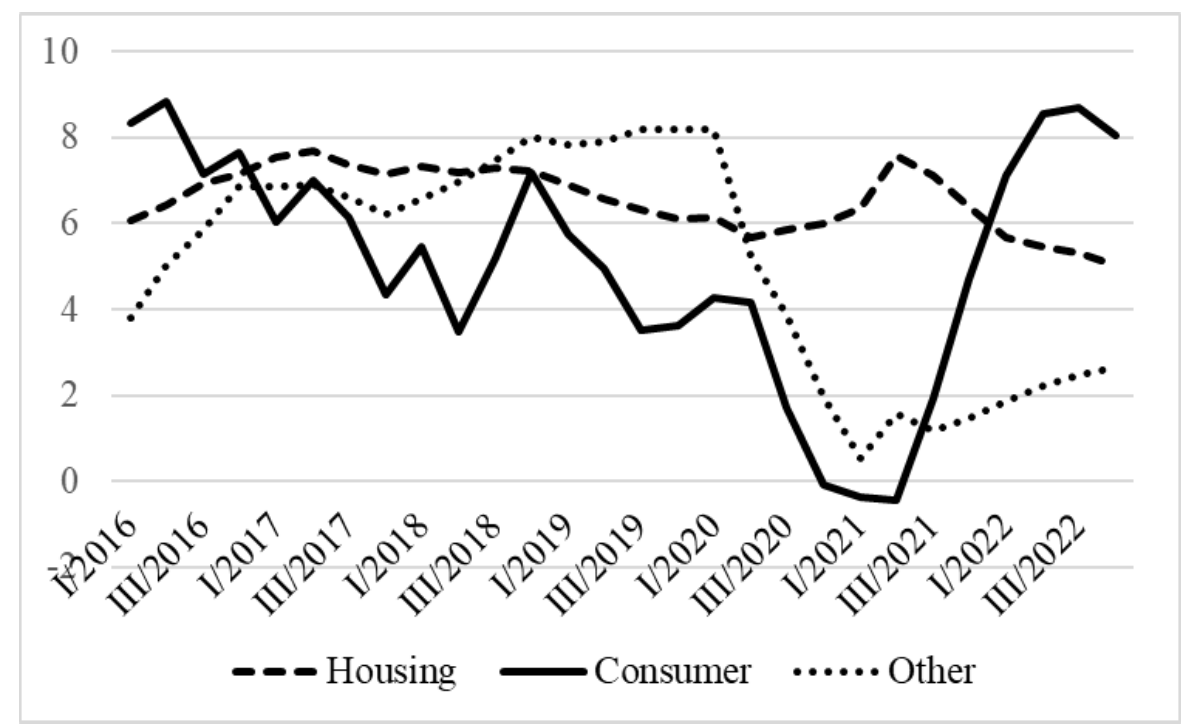

Figure 7. Prediction of the development of household loans (growth rate in\%).

Source: CNB owen processing (2021) 


\section{Discussions and Conclusin}

The result showed that Czech households are a frugal nation; their indebtedness is one of the lowest in the EU. Expansive growth saving domácnosti started in consequently with deferred consumption, total savings were generated at the time of covid 19 as forced savings. The government's measures in the context of wage policy (contributions to the adjustment of wages, remuneration of rescue workers, etc.) together with the unrealized consumption dynamize the creation of savings. The CNB's forecast that savings will decline at the beginning of 2021 has been confirmed (Michálek and Slezáčková, 2021), due to the growth of consumer consumption, on which the Ministry of Finance's forecast for 2022 is predicted an increase of $5.7 \%$. If the current economic recovery continues, there should be a recovery in consumption and a consequent reduction in forced savings. If the development of interest rates on deposit accounts copied the increase in the CNB's basic repo rate (an increase of 0.75 percent point to $1.5 \%$ ), then the forced savings could fall much more slowly. Halthough CNB interest rates were higher at the beginning of 2021, commericial banks are procrastinating with the growth of rates on deposit accounts, which can help stop the increase in savings and eliminate the effects the growth of the price level, which is now about $4.5 \%$. As regards the decline in growth dynamics of mortgage borrowing is due to rising prices in the real estate market. Real estate prices are already unaffordable for many Czech residents, and many municipalities consider returning to city apartments. The decline in the growth rate of mortgage loans will be based on the current development of interest rates. Compared to previous years, when mortgage interest rates remained below $2 \%$, they recorded an increase and reached the level of $3.5-5 \%$. The growth rate of other loans will increase from 2022, and a similar development is expected in the case of the growth rate of consumer loans, which, however, will decline at the end of 2022 (see Figure 7), probably due to rising interest rates. Compared to the crisis period, when households did not have confidence in the business environment, they invested more in stocks and commodities during a pandemic, which may indicate a higher financial literacy of the population. The development of savings and the use of credit products will be further affected by uncertainty in the labor market, where the economy is still affected by the epidemic, dysfunctional supply chains in the automotive industry).

Monitoring the development of indebtedness is necessary to quantify risks, as household over-indebtedness causes social anomalies in social exclusion, crime and savings for the necessary investments. It is necessary to realize "that money is a good mentor, but a bad servant."

\section{Acknowledgements}

The paper is finance from the project Development of R\&D Capacities of the Silesian University in Opava CZ. 02.2.69/0.0/0.0/18_054/0014696.

\section{References}

1. Beck, K., \& Janus, J. (2016). Podobieństwo wstrząsów podażowych i popytowych w Polsce i innych krajach Unii Europejskiej. Ekonomista, 1, 112140.

2. Cagetti, M. (2003). Wealth accumulation over the life cycle and precautionary savings. Journal of Business \& Economic Statistics, 21(3), 339-353.

3. CNB. ARAD. (n.d.). ARAD time series database. Retrieved August 9, 2021, from https://www.cnb.cz/cnb/STAT.ARADY_PKG.STROM_DRILL?p_strid=0\&p_1 ang $=\mathrm{CS}$.

4. Campbell, J. Y., \& Manki, G. N. (1989). Consumption, income and interest rates: reinterpreting the time series evidence. MIT Press

5. Canzoneri, M., Cumby, R., \& Diby, B. (2015). Monetary policy and the Natural Rate and Interest. Journal of Money, Credit and Banking, 47(2/3), 1-31. 
6. Eurostat. (2021a, September 10). Household saving rate. https://ec.europa.eu/eurostat/databrowser/view/teina500/default/table?lang=en.

7. Eurostat. (2021b, September 10). Gross debt-to-income ratio of households, https://ec.europa.eu/eurostat/databrowser/view/tec00104/default/table?lang=en.

8. Fisher, P. J., \& Montalto, C. P. (2010). Effect of saving motives and horizon on saving behaviors. Journal of Economic Psychology, 31(1), 92-105.

9. Grigoli, F., Herman A., \& Schmidt-Hebbel, K. (2018). Saving in the world. World Development, 104, 257-270.

10. Huang, F. W. (2020). A simple model of financial grey rhino under insurer capital regulation. Applied Economics, 52(46), 5088-5097.

11. Kim, J., \& Chatterjee, S. (2013). Childhood financial socialization and young adults' financial management. Journal of Financial Counseling and Planning, 24(1), 61-79.

12. Loayza, N., S., Hebbel, K., \& Servén, L. (2000). What drives private saving across the world? Review of Economics and Statistics, 8(2), 165-181.

13. Michálek, O., \& Slezáková, E. (2021, May 7). Pandemie dramaticky zvýšila míru úspor domácností. ČNB. https://www.cnb.cz/cs/menova-politika/zpravy-omenove-politice/boxy-a-clanky/Pandemie-dramaticky-zvysila-miru-uspordomacnosti/.

14. Newmeyer, C., Warmath, D., O'Connor, GE., \& Wong, N. (2021). Is savings automation helpful to liquid savings? It depends on whether you have a savings habit. Journal of Public Policy \& Marketing, 40(2), 285-297.

15. Mitriková, J., Šenková, A., Antolikova, S., \& Párová, V. (2016). The analysis of shopping behaviour in the context of spending leisure time activities of consumers in the chosen shopping centres in Vienna (Austria). Economic AnnalsXXI, 161(9-10), 71-74.

16. Pasalicova, R., \& Stiller, V. (2004). Credit and household consumption. Finance A Uver-Czech Journal of Economics and Finance, 54(11-12), 520 - 540.

17. Pécsyová, M., Vaňko, M., \& Machlica, G. (2013). Determinanty miery úspor na Slovensku (so zameraním na krízový rok 2009). Národohospodářské otázky, 21(10), 10-14.

18. Shin, S. H., \& Kim, K. T. (2018). Perceived income changes, saving motives, and household savings. Journal of Financial Counseling and Planning, 29(2), 396409.

19. Shida, Y. (2015, October). Forced savings in the soviet republics: Reexamination. HERMES-IR. http://hermes-ir.lib.hitu.ac.jp/hermes/ir/re/27497/RRC_WP_No54.pdf.

20. Schunk, D. (2009). What determines household saving behavior? An examination of saving motives and saving decisions. Jahrbucher fur Nationalokonomie und Statistik, 229(41), 467-491.

21. Tuček, M. (2020, August 30). Česká veřejnost o nezaměstnanosti - červenec 2020. CVVM. https://cvvm.soc.cas.cz/cz/tiskove-zpravy/ekonomicke/praceprijmy-zivotni-uroven/5271-ceska-verejnost-o-nezamestnanosti-cervenec-2020.

22. Ye, D. Z., Pan, S., Lian, Y. J., \& Ng, Y. K. (2021). Culture and savings: Why do Asians save more? Singapore Economic Review, 66(3), 621-651.

23. Zhua, A. Z. Y. F., \& Chou, K. L. (2018). Retirement goal clarity, needs estimation, and saving amount: Evidence from Hong Kong, China. Journal of Financial Counseling and Planning, 29(2), 018, 328-342. 